\title{
Establishing a Multi-Stakeholder Board for Multinational \\ Corporations
}

\author{
CHU Ho Ting, Hugo \\ Faculty of Law \\ The University of Hong Kong
}

\begin{abstract}
Several corporate scandals are related to lack of concerning stakeholders' interest. The voice of enhancing stakeholders' engagement in corporate governance framework is increasing. The paper is aimed to determine the pragmatic and applicable one-tier and two-tier board models for integrating stakeholders as board directors in multinational corporations. It begins with discussing why multinational corporations need to concern on stakeholders' interest and analysing different theoretical approaches for linking board composition with financial performance and corporate social performance. It will then review corporate governance frameworks integrating stakeholders' engagement in various jurisdictions and economic status (i.e. emerging markets and developed markets). Finally, pragmatic multi-stakeholder board models for one-tier and two-tier board structures will be proposed through defining board composition, CEO duality and mechanism to resolve disputes arise from board members.
\end{abstract}




\section{Introduction}

Multinational corporations (MNC, also known as multinational enterprises, transnational corporations or global corporations) refer to enterprises which operate in all sectors of the economy and usually comprise companies or other entities established in more than one country (OECD, 2011). There are two main characteristics of MNCs: 1) large size of firm; and 2) parent companies centrally control their worldwide activities (Zhang, 2003). Therefore, a MNC board's decision which may cause the success or failure of a MNC will affects the livelihood of tens of thousands of its employees and their families. Moreover, MNCs always contribute to the economies of both home and host countries, especially contributing to economies of developing countries through providing job opportunities, capital (foreign direct investment) and technology. In the perspectives of international politics, some large MNCs also have their political influence and diplomatic function (Nye, 1974; Irogbe, 2013). Therefore, quality of MNCs' board decision is crucial, as it affects not only the corporations, but also economies and societies of relevant countries.

Unfortunately, as shown in Table 1 below, numerous corporate scandals were happened in recent years. These scandals generally were caused by unethical decision-making and lack of concerning stakeholders' interest. For example, the defective ignition switches scandal of General Motors (GM) have been linked to at least 97 deaths from 2005 to 2014. However, evidence has shown that top management of GM knew the issue of defect since at least 2003 (Plumer, 2015). The scandal damages not only customers' interest, but also shareholders' interest, especially minority shareholders.

Table 1: MNCs' corporate scandals in recent years

\begin{tabular}{|l|l|l|}
\hline Years & Company & Corporate Scandal \\
\hline 2001 & Enron & Misrepresenting of financial statements \\
\hline 2002 & WorldCom & Accounting fraud \\
\hline 2003 & Parmalat & Accounting fraud \\
\hline 2006 & Siemens & Bribing business partners and employee representatives \\
\hline 2007 & Toyota & Unintended acceleration predicament caused deaths \\
\hline 2008 & Lehman Brothers & Accounting fraud \\
\hline 2010 & Foxconn & Suicide of workers due to poor working condition \\
\cline { 2 - 3 } & BP & Oil spill \\
\hline 2014 & General Motors & Defective ignition switches caused deaths \\
\hline 2015 & Volkswagens & Circumventing emission test \\
\cline { 2 - 3 } & Nestle & Using slave labours in Thailand \\
\hline 2016 & Apple & Tax avoidance \\
\hline
\end{tabular}


Moreover, the Volkswagens and Siemens cases showed that weak oversight of board and lack of outsiders in the board to provide independent advice (Milne, 2007; Bryant and Milne, 2015; Van der Heyden, 2015). In addition, some of the scandals are related to environmental injustice and human rights abuses, including forced eviction, pollution, violence, sexual abuses and child labour. Foxconn's workers suicide scandals, BP's oil spill and Nestle's slave labours scandal are typical examples.

\section{Shareholder supremacy norm and corporate scandals}

It is not exaggerated to say that shareholder supremacy norm is a dominant philosophy in corporate governance. The doctrine of shareholder supremacy norm is that management of a company should strive to maximize value for its shareholders (Macey, 2008). The dominance of shareholder supremacy norm in corporate governance is mainly achieved by two classical theories of corporate finance: agency theory and stewardship theory. Agency theory defines an agency relationship as a contract under which the principal (shareholders) engage the agent (directors or manager) through to perform service on their behalf. The divergence of the interests between principal and agent can be aligned by offering appropriate incentives to agent and incurring monitoring costs designed to limit the aberrant activities of the agent (Jensen and Meckling, 1976). Stewardship theory suggests stewards (directors) have a fiduciary duty to protect the interests of the principals (shareholders) and to make decisions on their behalf (Letting et al., 2012). As stewards have the legal duty to act for their principal, they must put their principals' interest on the first priority when there is any conflict of interests between principals and other stakeholders (Tricker, 2009). Backed by the two theories, shareholder supremacy norm protects and maximizes the interest of shareholders (i.e. profit maximization of shareholders). However, the stewards and agents may lead to short-termism and externalization of costs in order to enhance their performance (Smith 2003; Stout, 2012), and possibly causes the illegal and unethical corporate scandals.

\section{Stakeholder theory and independent directors}

Stakeholder theory brings alternative perspective in corporate governance. Stakeholders are defined as any group of individual who is affected by or can affect the achievement of an organization's objectives (Freeman 1984). They are commonly classified into two categories: internal stakeholders (including shareholders, boards of directors, managers and employees) and external stakeholders (including suppliers, customers, creditors, government agencies, communities and environment) (Mitroff, 1983; Cavanagh and McGovern, 1988; Ferrell et al., 2009). Stakeholder theory suggests that directors should address the interest of all stakeholders in a firm (Jensen, 2002). Different from agency and stewardship theories, stakeholder theory creates value to all stakeholders (Argandona, 2011), enhances the legitimacy of corporate decision (Jensen, 2002) and presents corporate morality (Jones, 1995). 
The stakeholder perspective is strongly linked to corporate social responsibility (CSR) (Jamali, 2008) and thus it may prevent corporate scandal and unethical corporate decision. In certain civil-law jurisdictions with two-tier corporate board structure, such as Germany and Japan, stakeholder theory has been adopted in some extent. The supervisory boards contain employees' representatives in addition to directors chosen by shareholders to appoints the management board, which is responsible for the operational management of the corporation, and oversees its actions (Dinh, 1999). The system protects the interest of employees and reduce the conflict between management and workers. Moreover, employees' representatives can also be found in one-tier boards in some civil-law jurisdictions, such as Sweden and Norway (Conchon, 2013). However, the concept of employees' representatives has not addresses externalities produced by the firm, such as effects on the environment or consumers (Gelter, 2016).

Moreover, under the Anglo-American shareholder supremacy governance model, directors who are appointed by the shareholders and managers who are employed by directors have no right to spend company resources for the interest of outsiders (Ambler and Wilson, 1995). However, in past three decades, independent directors play an important role in managing conflict of interest of board directors and managers especially under the one-tier board system (Cox, 2003). Resource dependence theorists suggests that independent directors can provide more resource, such as independent advice and external connections, and legitimacy to the board, while they are knowledgeable about the changing demand of various stakeholders (Ayuso and Argandona, 2007). Therefore, in certain extent, independent directors are expected to be custodians of stakeholders' interests (De Masi and Paci, 2014).

However, independent directors are elected/appointed by shareholders/management. When there is a conflict between shareholders and other stakeholders, it is expected that independent directors should primary protect the interest of shareholders. Moreover, the independence of independent directors is questioned. Empirical studies indicated that independent directors appointed during a CEO's tenure may similarly beholden to the CEO (Morse, Nanda and Seru, 2011; Coles et al., 2013). A research found that companies with dispersed ownership structures misclassify directors as independents more frequently than do companies with large controlling owners (Crespi-Cladera and Pascual-Fuster, 2013). Therefore, independent directors are not an effective way to protect stakeholders' interest and to prevent unethical corporate decision.

\section{Multi-stakeholder board}

In recent decade, the voice of enhancing stakeholders' engagement in corporate governance framework is increasing due to corporate scandals and controversies on corporate activities. Countries introduce initiatives in their corporate governance framework to enhance directors' concern on stakeholders' interests. Companies, especially MNCs, cannot afford to ignore stakeholders' 
interests as all stakeholder groups contribute to companies' success (Nwanji and Howell, 2005). They are increasingly to engage with stakeholders at a much earlier stage of their corporate project than in the past (IFC, 2007). However, Spitzeck and Hansen (2010) argue that the dialogue-based and advisory-based stakeholder engagement activities are incapable to observe all stakeholders' needs, and suggest to give stakeholders real power on decision making process.

Moreover, Huse and Rindova (2001) indicated that various stakeholders have different expectations of board roles. Therefore, stakeholders participating in company's boards of directors could be an effective way for balancing conflict of interests among stakeholders and improving its social performance (Wang and Dewhirst, 1992), and legitimizing boards' decisions (Shahzad et al., 2016). Indeed, the concept of multi-stakeholder governance which brings stakeholders together to participate in dialogue and decision making for common problems or goals is gradually adopted in the governance of global non-governmental organizations (Vallejo and Hauselmann, 2004). Applying the concept in corporate governance is encouraged (Kochan and Rubinstein, 2000; Ayuso and Argandona, 2007; Blount, 2015). Table 2 illustrates the key difference between the concept of shareholder and stakeholder governance model.

Table 2: Key distinctions between shareholder and stakeholder perspectives (Kochan and Rubinstein, 2000)

\begin{tabular}{|l|l|l|}
\hline & Shareholder perspective & Stakeholder perspective \\
\hline Purpose & Maximize shareholder wealth & $\begin{array}{l}\text { Pursue multiple objectives of parties } \\
\text { with different interests }\end{array}$ \\
\hline Governance structure & $\begin{array}{l}\text { Principal-agent model (managers } \\
\text { are agents of shareholders) }\end{array}$ & Team production model \\
\hline Governance process & Control & $\begin{array}{l}\text { Coordination, cooperation and } \\
\text { conflict resolution }\end{array}$ \\
\hline Performance metrics & $\begin{array}{l}\text { Shareholder value sufficient to } \\
\text { maintain investor commitment }\end{array}$ & $\begin{array}{l}\text { Fair distribution of value created to } \\
\text { maintain commitment of multiple } \\
\text { stakeholders }\end{array}$ \\
\hline Residual risk holder & Shareholders & All stakeholders \\
\hline
\end{tabular}

However, opponents of such stakeholder democracy fears that it takes long time to generate consent in a board, and thus may produces inefficient decision and affects the profitability of a company (Hansmann and Kraakman, 2000). Therefore, in the next section, it will discuss the relationship between stakeholders' governance, efficiency on decision making, and corporate performance. It will then study some stakeholder engagement initiatives introduced in various countries' corporate governance frameworks in recent decades. Finally, it will seek the pragmatic way to establish multistakeholder board under both one-tier and two-tier board regimes. 


\section{Stakeholders Governance, Efficiency and Corporate Performance}

Critics of stakeholder governance argued the decision making process of such approach is inefficient and thus negatively affects corporate performance. Indeed, multi-stakeholder boards aim to make legitimate decision in which interests of all stakeholders are balanced and the external costs are internalized. A trade-off should be made for making quality decision. However, it does not mean that we can ignore the time cost in order to make the most optimized decision. Figure 1 in below which is introduced by Vallejo and Hauselmann (2004) shows the interdependence between legitimacy and efficiency. The red curve shows the diminishing of the speed as the increase of stakeholder participation while the blue curve shows the enhancement of legitimacy through increasing participation of stakeholders. The intersection of the two curves (point $\mathrm{O}$ ) represents an optimal level of efficiency. The green area surrounding point $\mathrm{O}$ is the zone of efficiency. Outside the green area can be described as inefficient. It is expected that a multi-stakeholder board has to try to meet the green area when it makes trade-off between legitimacy and efficiency.

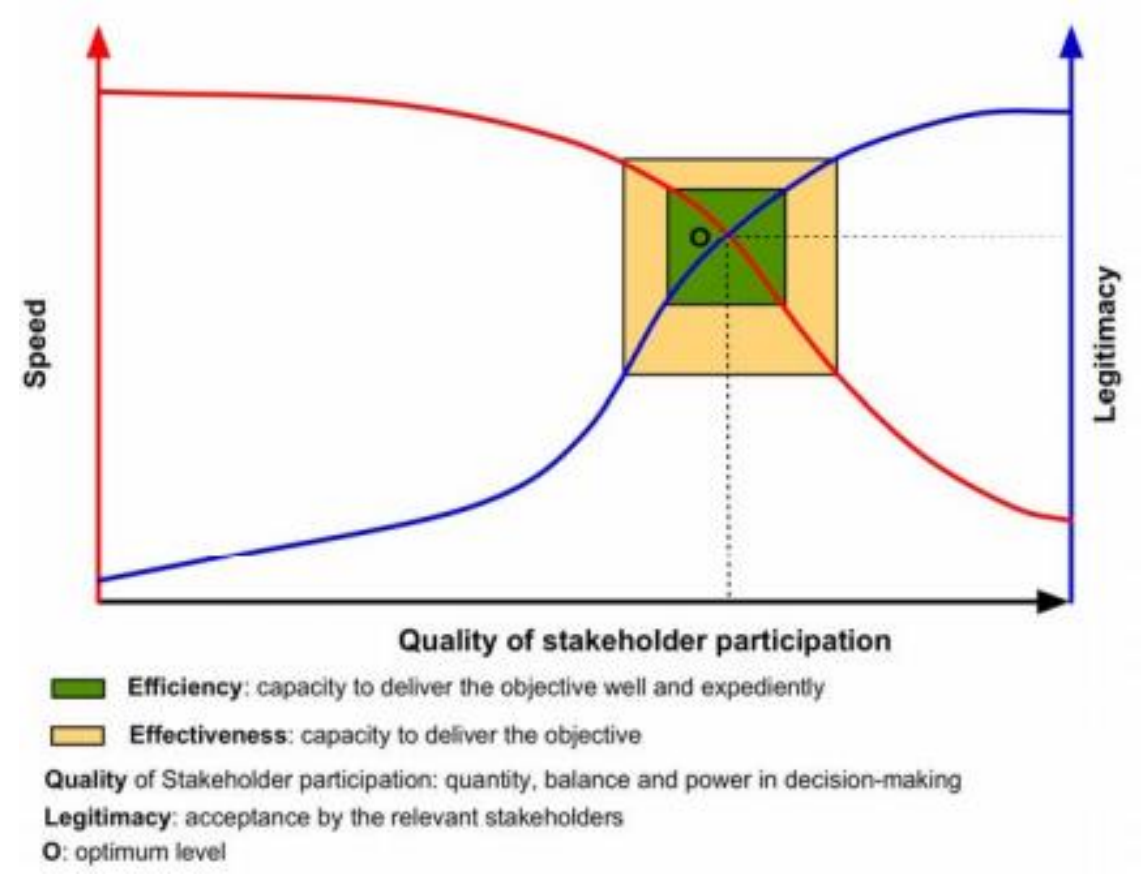

Figure 1: Speed versus legitimacy (Vallejo and Hauselmann, 2004)

The "green area" of efficiency is an abstract concept. Nevertheless, three of the six main features of multi-stakeholder initiative highlighted by Ruggie (2008) provides a good guidance for making a relatively efficient decision through a multi-stakeholder board, including clarity of purpose, involvement of relevant stakeholders and transparency. Firstly, clarity of purpose means that a multi-stakeholder board should has a clear scope of mission. Shareholders and stakeholders must come together to decide (or shareholders have a discretion to decide) which matters require multi- 
stakeholder board to decide. Secondly, a stakeholders mapping is required to define which kind of stakeholders are relevant to be included into a board. Thirdly, optimal level of transparency drives an efficient decision-making process. The features enhance the efficiency of the decision-making process. Details of multi-stakeholder board's scope of mission and stakeholders mapping will be discussed in section 4 of this paper.

\subsection{Stakeholders Governance and Corporate Social Performance}

In addition to efficiency, corporate performance is another concern. Corporate performance can be divided into corporate social performance (CSP) and corporate financial performance (CFP). CSP can be defined as companies' configuration of principles of social responsibility, processes of social responsiveness, and policies, programs, and observable outcomes as they relate to the firm's societal relationships (Wood, 1991). It is the extended concept of CSR that place more of an emphasis on result achieved (SAGE, 2012).

Stakeholders governance which included the voice of external stakeholders in corporate boards, such as environment and retail customers, is possible to make ethical and social responsive decision, and thus to enhance companies' CSP. Empirical studies on the relationship between stakeholder governance and CSP also support this argument (Coffey and Wang, 1998; Brower and Mahajan, 2010; Taneja et al., 2017). Besides, researches found that board diversity positively affects companies' CSR performance (Sanchez et al., 2011; Harjoto et al., 2014) and positively relates to transparency in companies' reporting of social and environmental performance (Frias-Aceituno et al., 2013). Board diversity is one of the key feature of a multi-stakeholder board. Therefore, the adoption of multi-stakeholder board could enhance companies' CSP.

\section{Corporate social performance and corporate financial performance}

There is a long debate about the relationship between CSP and CFP. The relationship could be neutral, positive and negative. Supporters of negative relationship argue that engaging in CSR activities creates few economic benefits and incurs costs that could be avoided, and thus decreases the CFP (Friedman, 1970; Aupperle et al., 1985). From this viewpoint, the main concern is whether multi-stakeholder boards decrease CFP in order to enhance CSP.

Simionescu (2015) initiates CSR activities with stakeholder ability to influence (SAI) could make positive relationship with CFP. SAI is defined as the ability of a company to identify, act on and profit from an opportunity to improve stakeholder relationships through CSR. Simonescu argued that CSR activities that do not generate SAI will not create any return from CSR activities and thus affects CFP, while CSR activities which target the improve of stakeholder relationship leads later on to successful CFP. Indeed, multi-stakeholder board which empower stakeholders voting rights on board is the most effective mechanism to increase SAI. Moreover, Ayuso and Argandona (2007) 
argued that a board with diverse stakeholders will promote CSR activities within a firm and will ultimately lead to better financial performance of a firm.

\subsection{Stakeholders Governance and Corporate Financial Performance}

On the other hand, with the viewpoint of positive or neutral CSR-CSP relationship, the main concern is whether multi-stakeholder boards can directly benefit on CFP. Numbers of empirical studies found that board diversity and stakeholders' involvement in corporate governance are positively associated with CFP (Baysinger and Bulter, 1985; Ezzamel and Waston, 1993; Ayuso et al., 2007). Good CFP (in terms of return on assets, return on equity and return on sales) and quality of management go along with good treatment of stakeholders like employees, customers and communities (Waddock and Graves, 1997; Berman et al., 1999). Moreover, Schwarcz (2016) found that the inclusion of bondholders in corporate board could help companies to reduce systemic risk and enhance companies' CFP. It is because bondholders, same as shareholders, concern on the performance of companies they invested and concern on risk perspective than shareholders.

Resource dependence theory provides a good explanation on the relationship between stakeholders' governance and CFP. As mentioned, the theory underlines the role of directors as resource providers (Hillman et al., 2000). A multi-stakeholder board which composed by stakeholders from various constituencies brings valuable resources, including expertise, business/non-business connection and innovation, to a company and enhances CFP. For example, suppliers' and customers' representatives may bring connection of the upper and lower part of the value chain. It may help the cost control of the company, make any potential synergy through the connection to enhance CFP. 


\section{Stakeholder Engagement in Global Corporate Governance Framework}

This paper aim to seek the pragmatic way to establish a multi-stakeholder board under both one-tier and two-tier board regimes. Therefore, it is necessary to understand and review the existing corporate governance structures and initiatives implemented for stakeholder engagement and stakeholder governance in both developed and developing countries.

\subsection{Corporate Governance Framework}

There are generally two types of corporate board structures depending on the legal origin of a jurisdiction (Deakin, 2013). Jurisdictions with common-law tradition, such as the US the UK and Hong Kong, generally adopt variants of the one-tier board structure. On the other hand, two-tier board structure is generally adopted in civil-law jurisdictions, such as Germany and Japan. However, some civil-law jurisdictions, such as Norway and Sweden, adopt one-tier structure. Jurisdictions like France, Romania and Italy allow companies to choose between the two types of board structures.

Under one-tier structure, board members, include executive directors and non-executive directors, are elected by the shareholders in shareholders' meeting and plays both management and supervisory functions. The board leadership structure in one-tier boards can be variant. Some boards separate the role between chief executive officer (CEO) and board chairman while others combine the two roles. This is referred as CEO duality (Maassen, 2002). One-tier boards also make often use of board committees to carry out specified functions assigned boards, such as audit and remuneration committees. Also, as mentioned, there is a fraction of seat in one-tier boards for independent directors. Besides, in some European countries with one-tier structure, such as Sweden and Norway, employee representatives should be included in corporate boards. Different from the one-tier board with stakeholder supremacy structure, all board members in Swedish companies are non-executive.

Two-tier structure, which includes supervisory board and management board, is designed to separate the executive function of a board from its monitoring function (Maassen, 2002). Supervisory board, consists of non-executive supervisory directors, oversees and advises management board's works while management board, consists of executive directors, performs management and day-to-day operation functions. The hierarchal relationship between two boards is variant in different countries. For example, in Germany and Austria, supervisory board members are elected by shareholders in shareholders' meeting (except employee representatives whose elected by employees and trade union). The board owns the power to appoint and dismiss the management board. In China and France, however, member of both supervisory board and management board of a company are elected by shareholders in shareholders' meeting. Employees' representatives are included in supervisory boards in some countries, such as Germany and Japan, but excluded from the boards in other countries, 
such as Belgium and Romania (Conchon, 2013). Moreover, CEO has no seat in the supervisory board. Therefore, board leadership of two-tier structure is independent from the executive function of the board (Maassen, 2002).

With no standardized corporate governance framework, the Organisation for Economic Co-operation and Development (OECD) has published "G20/OECD Principles of Corporate Governance" to provide an international benchmark for good corporate governance. The role of stakeholders in corporate governance has been covered in the principles. It requires that corporate governance frameworks should recognize stakeholders' rights through legislation or mutual agreements, and provide stakeholders opportunity to obtain effective redress for violation of their rights (OECD, 2015). The principles also expect corporate boards to take due regard of, and deal fairly with, stakeholders' interests, and support mechanisms for employee participation. Although the principles are non-legal binding, initiatives in many countries are introduced in accord with the principles (Ajibo, 2014).

\subsection{Initiatives for stakeholder participation}

Continental European countries which adopt two-tier board structure have mechanism for stakeholder participation on board, while countries adopt one-tier board structure trend to apply fiduciary duties of directors to stakeholders' interest, and enhance stakeholders' participation through appointment of independent directors and stakeholder engagement.

\section{Corporate Co-determination and stakeholder representatives}

Co-determination refers to a concept for employee consultation and participation in company decisions (Muswaka, 2014). Even though the UK was probably the first country to legislate for codetermination on corporate boards (McGaughey, 2014), it currently adopts shareholder supremacy approach. The German two-tier corporate governance structure is typical model of corporate codetermination. The German Co-determination Act of 1976 is modern legislation for corporate codetermination which designates the composition of supervisory boards. In company with less than 2,000 employees, employee representatives occupy one-third of the supervisory board. In company with more than 2,000 employees, the employee representatives are nominated by employees, trade union/work council, and elected by employees. Moreover, in companies with more than 1,000 employees and conducting iron, steel and coal businesses, employee representatives occupy half of the supervisory board. These representatives are nominated by trade union and work council, and elected by shareholders meeting. Therefore, both employees of a company and labour community hold the stake in the German company's supervisory board.

Different from Germany, the corporate governance framework of France requires supervisory boards to include not only employees' representatives (which is nominated by employees and trade union 
and elected by employee), also minority shareholders' representatives. The minority shareholders' representatives are appointed as independent directors, in a variable proportion depending on the shareholding structure of the company. Moreover, the French company law requires listed companies to have a minimum of $40 \%$ female representation on boards by 2017 (IFA and PIFCE, 2015).

Co-determination is also applied in one-tier board structure. In Sweden, companies with activities in several branches and at least 1000 employees can have three employees' representatives (and three deputies who can attend board meeting with a consultative voice) appointed by trade union. However, the maximum number of employee directors may never exceed half of the board (Conchon, 2013).

The corporate governance framework of India which adopts shareholder supremacy model has no codetermination concept. However, under Indian Companies Act 2013, each listed company in India is required to appoint at least one female director on its board. It is rare case that stakeholder representative is included in shareholder supremacy board structure.

\section{Directors' fiduciary duties applied to stakeholders' interest}

Most of the common-law jurisdictions, which adopt shareholder supremacy model, expand directors' fiduciary duties to cover stakeholders' interest and enhance disclosures for enabling stakeholders to make an informed assessment on companies. In the UK, enlightened shareholder value is introduced through its Companies Act 2006. Enlightened shareholder value requires directors to consider stakeholder's interests for the purpose of enhancing shareholders' long term value (Naniwadekar and Varottil, 2016). However, shareholder interest should be first considered when there is conflict of interest between shareholders and other stakeholders.

India takes another approach through its Companies Act 2013. It requires directors to act in the best interests of the company and all stakeholders, including shareholders, without creating any hierarchy. Moreover, a Stakeholder's Relationship Committee and a Corporate Social Responsibility Committee are established under the board in each Indian listed company mandated by the Companies Act 2013. The former which is chaired by an independent director aims to redress the grievances of stakeholders, while the latter, which consists of at least 3 directors of whom at least one should be independent, aims to formulate CSR policy and to ensure company to spend at least $2 \%$ of its net profits on CSR activities. Comparing with the British approach, the Indian approach provide equal treatment to the interest of shareholders and other stakeholders. However, stakeholders have no representative on boards. 
Similar to the value of the Indian approach, the stakeholder-inclusive approach adopted in the corporate governance framework of South Africa. It requires directors to considers the legitimate interests and expectations of stakeholders as the best interests of the company, and to treat the interest of shareholder and other stakeholders equally (IoDSA, 2009). The King Code of Governance Principles (King III) which emphasis more on the interaction between company and its stakeholders (Vorster and Marais, 2014) requires boards to develop mechanism for constructive stakeholder engagement, to implementing stakeholder strategies and policies, and to report financial, ethics and social performance to all stakeholders. Also, it requires that board chairman should be an independent non-executive director. The King III code has no requirement on stakeholder representatives on board, however a set of Codes of Good Practice formulated in accordance with the Broad-Based Black Economic Empowerment Act 2003, an act led to the enrichment of disadvantaged people, require companies to ensure a reasonable percentage of their shares are in the hands of black people and to ensure the appointment of black people at board and managerial levels.

The corporate governance frameworks of the two financial centres, the US and Hong Kong, has no specific requirement on directors to act for stakeholders' interests and on appointing stakeholder representatives. Though the US Sarbanes-Oxley Act requires to increase the fraction of independent directors, the directors are viewed as more likely to prioritize the shareholders' interests (White, 2006). Hong Kong adopts "comply or explain" approach to require listed companies to publish environmental and social governance report to disclose non-financial performance to the public, including stakeholders and to publish corporate governance report which require companies to have policy concerning board diversity.

Table 3: Summary of corporate governance frameworks reviewed

\begin{tabular}{|l|l|l|l|}
\hline & $\begin{array}{l}\text { Board } \\
\text { Structure }\end{array}$ & $\begin{array}{l}\text { Interests that Directors } \\
\text { act for }\end{array}$ & $\begin{array}{l}\text { Stakeholder } \\
\text { Representative on Board }\end{array}$ \\
\hline Germany & Two-tier & Stakeholders & Employees \\
\hline France & Both & Stakeholders & Employees and female \\
\hline Sweden & One-tier & Stakeholders & Employees \\
\hline UK & One-tier & $\begin{array}{l}\text { Stakeholders (higher } \\
\text { priority for shareholders) }\end{array}$ & No \\
\hline India & One-tier & Stakeholders & Female \\
\hline South Africa & One-tier & Stakeholders & Black people \\
\hline US & One-tier & Shareholders & No \\
\hline Hong Kong & One-tier & Shareholders & No \\
\hline
\end{tabular}




\section{Proposed Multi-Stakeholder Board for Multinational Corporations}

Some countries' frameworks allow specific kind of stakeholder representatives, such as employees and women, or extend directors' fiduciary duties to stakeholders' interests. The frameworks only provide a minimum requirement for companies to comply with. Companies enhance stakeholder engagements on top of the statutory requirement. In the US, a shareholder supremacy regime, minority representation on board is scant under non-mandatory pressures (White, 2006; Russell, 2013). Therefore, it is possible to establish multi-stakeholder board under the current frameworks in both developed and developing countries.

\subsection{Scope of Mission}

Clarifying board's scope of mission enhances the efficiency of decision. For the company's internal issue, stakeholder representatives may not need to involve. For seeking the pragmatic way to building mechanism for stakeholder governance, co-determination is agreed as a core concept for the proposed multi-stakeholder board. Therefore, it can take reference to supervisory board's mission from the German Corporate Governance Code. It stated that the supervisory board is involved in decisions of fundamental importance to the company, including issues related to fundamentally change of company's asset, financial or earnings situations (Regierungskommission Deutscher Corporate Governance Kodex, 2014). Moreover, building such boards aim to make board's decision to address stakeholder's interest and to be more social responsive. Thus, multi-stakeholder board should be involved on the corporate decisions those will fundamentally affect company's financial situation and affect stakeholders' interests.

\subsection{Board Composition}

Stakeholder mapping is required for picking representatives of essential stakeholder groups, and limiting the board size. Indeed, many companies have defined their key stakeholders. For example, Atlas Copco, a Swedish-based global industrial group, has defined its key stakeholders in its Business Code of Practice (Atlas Copco, 2012). Also, Hong Kong's CLP Group has described their scope of diversity in their board diversity policy, including gender and ethnicity (CLP Group, 2016). It can be a foundation for further selection of representatives on board.

For stakeholders mapping, it, suggests to adopt the three group of classification made by Rodriguez et al. (2002) to differentiate among stakeholders. Table 4 shows the definitions and examples of the classification. 
Table 4: Classification of stakeholders (Rodriguez et al., 2002)

\begin{tabular}{|l|l|l|}
\hline Classification & Definition & Examples \\
\hline $\begin{array}{l}\text { Consubstantial } \\
\text { Stakeholders }\end{array}$ & $\begin{array}{l}\text { Stakeholders that are essential for } \\
\text { the company's existence }\end{array}$ & $\begin{array}{l}\text { Shareholders, minority shareholders, } \\
\text { investors and employees }\end{array}$ \\
\hline $\begin{array}{l}\text { Contractual } \\
\text { Stakeholders }\end{array}$ & $\begin{array}{l}\text { Stakeholders that have formal } \\
\text { contract with the company }\end{array}$ & $\begin{array}{l}\text { Creditors, suppliers, sub-contractors } \\
\text { and customers }\end{array}$ \\
\hline $\begin{array}{l}\text { Contextual } \\
\text { Stakeholders }\end{array}$ & $\begin{array}{l}\text { Stakeholders that are affected by } \\
\text { company's action in the non- } \\
\text { business and social perspective }\end{array}$ & $\begin{array}{l}\text { Communities, environments, trade } \\
\text { unions, government agencies and } \\
\text { opinion makers }\end{array}$ \\
\hline
\end{tabular}

Basically, representatives of consubstantial stakeholders should be included in the multi-stakeholder board. Stakeholder analysis matrix developed by Wye College (1998) to selecting representatives for non-profit multi-stakeholder initiatives, as Figure 2 shown, can also be adopted for the selection of representative on corporate board from contractual and contextual groups.

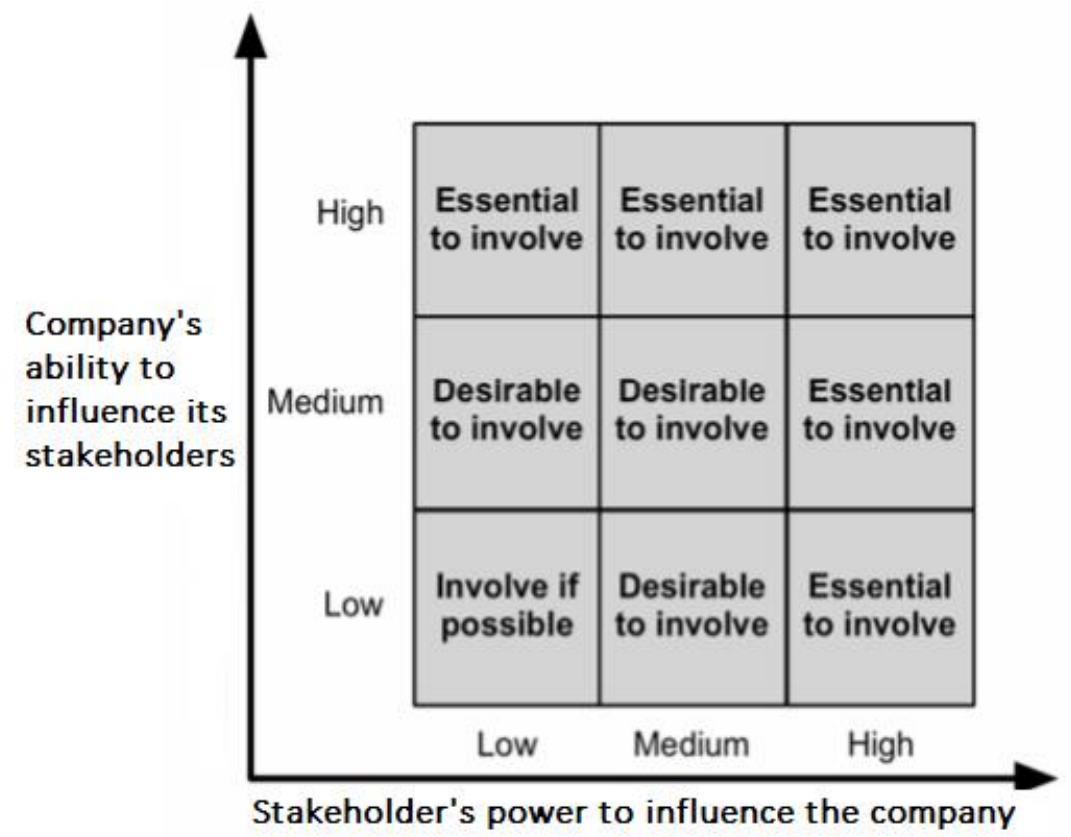

Figure 2: Stakeholder analysis matrix (Wye College, 1998)

The board make a high-level decision in a MNC. Thus, stakeholder representatives should be selected in broader perspective. It suggests to select environment's and customers' representatives from international organizations for environmental and customer protection. Issues of local customer or specific environment can be addressed by board committee for stakeholder engagement. Moreover, nomination committee should consider the diversity of gender and ethnic minority on board composition. Equal allocation between male and female on board is expected. 


\section{Board committee}

Committees under board for understanding specific stakeholders' need in local perspective is necessary. For example, a multinational oil company can establish a stakeholder relationship committee or a project-based ad-hoc committee composed by relevant stakeholder representatives for evaluating the effect of its project located in an African village to villagers and the ecosystem of the village through a dialogue-based stakeholder engagement, and for proposing a redress scheme to the board for villagers' grievances. Moreover, company can invite delegates of stakeholder groups without representation on board due to limit of board size to such committees for better stakeholders' communication and consultation.

\subsection{Multi-stakeholder Board in One-tier Structure}

Figure 3 shows the proposed multi-stakeholder board for one-tier structure. It suggests that all consubstantial stakeholders, including representatives of employees (but not trade union representatives) and minority shareholders, are included in the existing board of directors. Other stakeholders will be involved when the issue is subject to multi-stakeholder board.

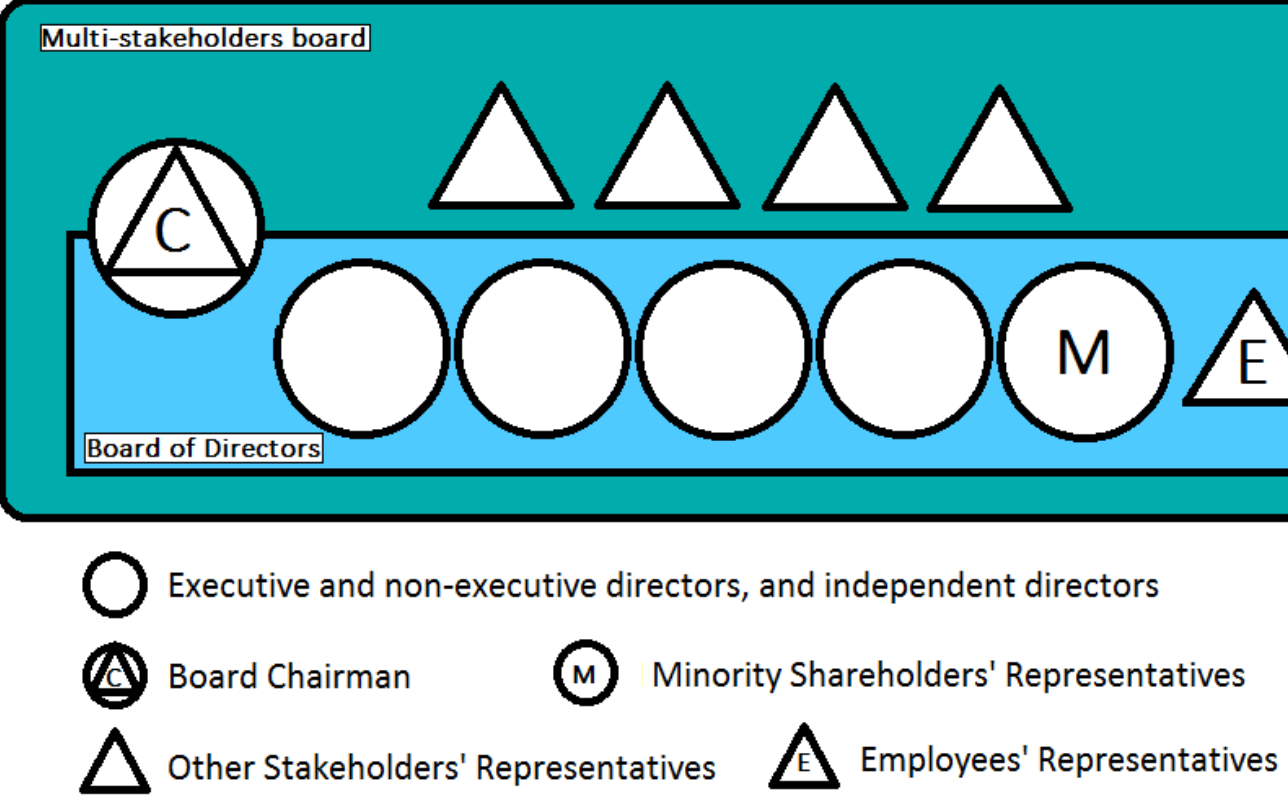

Figure 3: Proposed multi-stakeholder board for one-tier board structure

Number of stakeholder representatives, including employees' representatives, and number of board directors, excluding chairman, should be equally weighted. Chairman only can vote when the voting deadlock exists (i.e. casting vote). Therefore, it is expected that chairman should be an independent director. Moreover, alternative dispute resolutions (ADRs), such as mediation and arbitration, can used for resolving dispute arise from controversial decision or from incapability of chairman to 
exercise casting vote (e.g. conflict of interests). For example, mediation committee or arbitration committee can be established for the issue.

\section{CEO duality}

Though some researches show that CEO duality has positive linear relationship with accounting performance and financial strength (Lam and Lee, 2001; Tin and Shu, 2008), it reduces concern of stakeholders' interest (Benson et al., 2011). Also, Webb (2004) found that social responsible firms are most likely to separate the role of CEO from chairman. Hence, for the interest of stakeholders and companies' CSP, it suggests the board's chairman should not hold the position of CEO.

\subsection{Two-tier Board Structure}

Multi-stakeholder board can be pragmatically built on the foundation of the well-constructed dual board approach. Figure 4 shows All stakeholder representatives are included in the supervisory board of the proposed multi-stakeholder board. Representatives for stakeholders, including employees' representatives, and for shareholders in supervisory board should be equally weighted. As employees' representatives own one-third of supervisory boards in many European countries (onehalf in Germany), the equally-weighted supervisory board should be made through reducing seats for both existing number of shareholders' and employees' representatives or increasing the size of supervisory board.

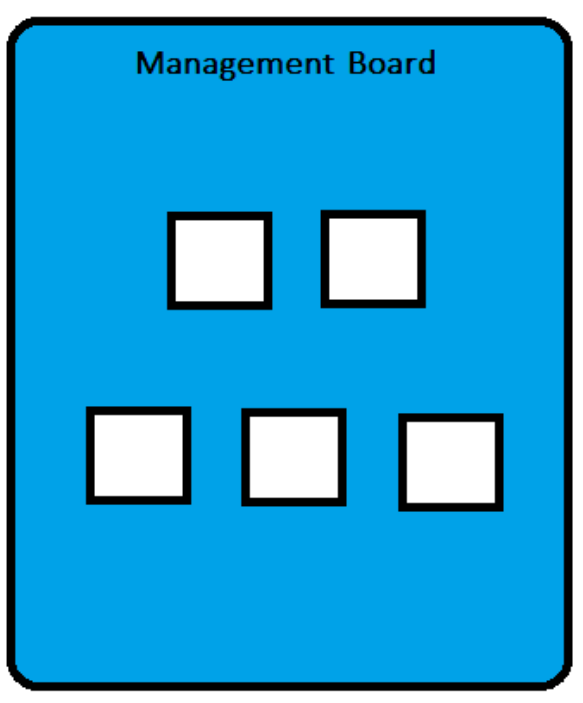

Executive Directors

Shareholders' Representatives

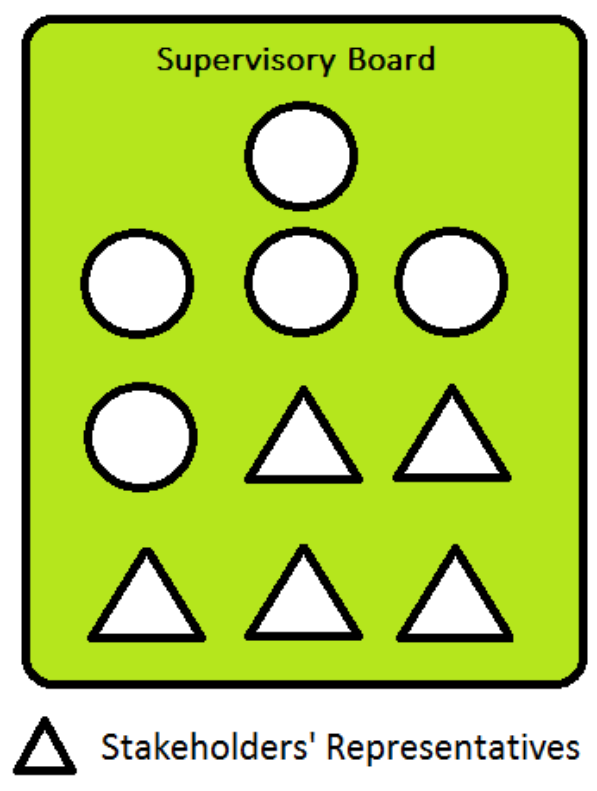

Figure 4: Proposed multi-stakeholder board for two-tier board structure 
The enlarged supervisory board check on the management board, and discuss and approve/reject proposal initiated by management board. Following the current rule of two-tier system, chairman of supervisory board has the casting vote to resolve deadlock. Also, Board committee and ADR mechanism mentioned in the previous section are also suggested to establish under this approach.

\section{Conclusion}

In conclusion, it is possible to establish multi-stakeholder board under the current corporate governance frameworks with minor regulatory adjustment. However, the difficultly is whether shareholders accept to lose their control on board in order to chasing stakeholder democracy (Blount, 2015). Moreover, the increasing of outsiders on board brings the issue of confidentiality (i.e. risk on information leakage) (Bainbridge, 2008). These factors make multi-stakeholder governance in MNCs a long way to go.

\section{Reference}

1. Ajibo, C. (2014). "A critique of enlightened shareholder value: Revisiting the shareholder primacy theory". Birkbeck Law Review, 2(1), pp.37-58

2. Altas Copco (2012). Business Code of Practice. Nacka: Brand Studio

3. Ambler, T. and Wilson, A. (1995). "Problems of stakeholder theory". Business Ethics, 4(1), pp.30-35

4. Argandona, A. (2011). "Stakeholder theory and value creation", IESE Business School, Working Paper, no.922

5. Aupperle, K.E., Carrol, A.B., and Hatfield, J.D. (1985). “An empirical examination of the relationship between corporate social responsibility and profitability". Academy of Management Journal, 28(2), pp.446-463.

6. Ayuso, S. and Argandona, A. (2007). "Responsible corporate governance: Towards a stakeholder board of directors?”, IESE Business School, Working Paper, no.701

7. Ayuso, S., Rodriguez, M.A., Garcia, R. and Arino, M.A. (2007). "Maximizing stakeholders' interests: An empirical analysis of the stakeholder approach to corporate governance", IESE Business School, Working Paper, no.670

8. Bainbridge, S. (2008). The New Corporate Governance in Theory and Practice. New York: Oxford University Press

9. Benson, B.W., Davidson, W.N., Wang, H. and Worrell, D.L. (2011). "Deviations from expected stakeholder management, firm value, and corporate governance”. Financial Management, 40(1), pp.39-81

10. Berman, S.L., Wick, A.C., Kotha, S and Jones, T.M. (1999). "Does stakeholder orientation 
matter? The relationship between stakeholder management models and firm financial performance”. Academy of Management Journal, 42(5), pp.488-506

11. Blount, J. (2015). "Creating a stakeholder democracy under existing corporate law". University of Pennsylvania Journal of Business Law, 18(2), pp.365-410

12. Brower, J. and Mahajan, V. (2013). "Driven to be good: A stakeholder theory perspective on the drivers of corporate social performance". Journal of Business Ethics, 117(2), pp.313-331

13. Bryant, C. and Milne, R. (2015, October 4). "Boardroom politics at heart of VW scandal". Financial Times. Retrieved from https://www.ft.com/content/e816cf86-6815-11e5-a57f$21 \mathrm{~b} 88 \mathrm{f} 7 \mathrm{~d} 973 \mathrm{f}$

14. Cavanagh, G.F. and McGovern, A.F. (1998). Ethical Dilemmas in the Modern Corporation. New Jersey: Prentice Hall

15. CLP (2016). CLP Holdings Limited Board Diversity Policy. Hong Kong: CLP Holdings Limited

16. Coffey, B.S. and Wang, J. (1998). "Board diversity and managerial control as predictors of corporate social performance". Journal of Business Ethics, 17(14), pp.1595-1603

17. Coles, J.L., Daniel, N.D. and Naveen, L. (2014). "Co-opted boards”. Review of Financial Studies, 27, pp.1751-1796

18. Conchon, A. (2013). Workers' Voice in Corporate Governance: A European Perspective. London: Trades Union Congress

19. Cox, J.D. (2003). "Managing and monitoring conflicts of interest: Empowering the outside directors with independent counsel". Villanova Law Review, 48, pp.1077-1095

20. Crespi-Cladera, R. and Pascual-Fuster, B. (2013). "Does the independence of independent directors matter?". Journal of Corporate Finance, Vol.28, pp.116-134

21. De Masi, S. and Paci, A. (2014). "Board composition in the public utilities: A focus on independent directors". Network Industries Quarterly, Vol. 16, No.3, pp.3-7

22. Deakin, S. (2013). "The legal framework governing business firms and its implications for manufacturing scale and performance: the UK experience in international perspective", Government Office for Science, Future of Manufacturing Project: Evidence Paper 5

23. Dinh, V.D. (1999). "Codetermination and corporate governance in a multinational business enterprise". Journal of Corporation Law, 24(4), pp.975-999

24. Ferrell, O.C., Fraedrich, J. and Ferrell, L. (2009). Business Ethics: Ethical Decision Making and Cases. Mason: South-Western Cengage Learning

25. Friedman, M. (1970, September 13). "The social responsibility of business is to increase its profits". The New York Times Magazine, 33

26. Freeman, R.E. (1984). Strategic Management: A Stakeholder Approach. Boston: Pitman

27. Frias-Aceituno, J.V., Rodriguez-Ariza, L., Garcia-Sanchez, I.M. (2013). "The role of the board in the dissemination of integrated corporate social reporting". Corporate Social Responsibility and Environmental Management, 20(4), pp.219-233

28. Gelter, M. (2016). "Employee participation in corporate governance and corporate social 
responsibility", Fordham University School of Law and ECGI, Working Paper, no.322

29. Gyapong, E. (2016) “Towards a 'hybrid' African corporate governance model: Evidence from post apartheid South Africa". Corporate Ownership \& Control, 12(3), pp.419-427

30. Hansmann, H. and Kraakman, R. (2000). "The end of history for corporate law", Harvard Law School, Discussion Paper, no.280

31. Harjoto, M., Laksmana, I. and Lee, R. (2014). "Board diversity and corporate social responsibility". Journal of Business Ethics, 132(4), pp.641-660

32. Hillman, A.J., Cannella Jr, A.A. and Paetzold, R.L. (2000). "The resource dependence role of corporate directors: Strategic adaption of board composition in response to environmental change". Journal of Management Studies, 37(2), pp.235-255

33. Huse, M. and Rindova, V.P. (2001) 'Stakeholders' expectations of board roles: The case of subsidiary boards". Journal of Management and Governance, 5, pp.153-178

34. IFA and PIFCE (2015). Corporate Governance in French Listed Companies: An Investor Guide. Paris: The French Institute of Directors

35. IFC (2007). Stakeholder Engagement: A Good Practice Handbook for Companies Doing Business in Emerging Markets. Washington D.C.: International Finance Corporation

36. IoDSA (2009). King Code of Governance for South Africa 2009. Johannesburg: The Institute of Directors in Southern Africa

37. Irogbe, K. (2013). "Global political economy and the power of multinational corporations". Journal of Third World Studies, 30(2), Fall 2013, pp.223-250

38. Jamali, D.J. (2008). "A stakeholder approach to corporate social responsibility: A fresh perspective into theory and practice". Journal of Business Ethics, 82(1), pp.213-231

39. Jensen, M. (2002). "Value maximization, stakeholder theory, and the corporate objective function”. Business Ethics Quarterly, Vol. 12, No. 2, pp.235-256

40. Jensen, M. and Meckling, W. (1976). "Theory of the firm: Managerial behavior, agency costs and ownership structure". Journal of Financial Economic, Vol. 3, No. 4, pp.305-360

41. Jones, T.M. (1995). "Instrumental stakeholder theory: A synthesis of ethics and economics". The Academy of Management Review, 20(2), pp.404-437

42. Kochan, T.A. and Rubinstein, S.A. (2000). "Toward a stakeholder theory of the firm: The Saturn partnership". Organization Science, 11(4), pp.367-386

43. Lam, T.Y. and Lee, S.K. (2008). "CEO duality and firm performance: evidence from Hong Kong”. The International Journal of Business in Society, 8(3), pp.299-316

44. Letting, N.K., Wasike, E.R., Kinuu, D., Murgor, P., Ongeti, W. and Aosa, E. (2012). "Corporate governance theories and their application to boards of directors: A critical literature review". Prime Journal of Business Administration and Management, 2(12), pp.782-787

45. Macey, J. (2008). Corporate Governance: Promises Kept, Promises Broken. New Jersey: Princeton University Press

46. Maassen, G.F. (2002). An International Comparison of Corporate Governance Models: A Study 
of the Formal Independence and Convergence of One-tier and Two-tier Corporate Boards of Directors in the United States of America, the United Kingdom and the Netherlands. Amsterdam: Spencer Stuart

47. McGaughey, E. (2014). "British codetermination and the Churchillian circle", UCL Labour Rights Institute, Working Paper, no.2

48. Milne, R. (2007, May 9). “Germany's two-tier governance system comes under fire”. Financial Times. Retrieved from https://www.ft.com/content/e222e59a-fd90-11db-8d62-000b5df10621

49. Mitroff, I. (1983). Stakeholders of the Organizational Mind: Toward a New View of Organizational Policy Making. San Francisco: Jossey-Bass

50. Morse, A., Nanda, V. and Seru, A. (2011). “Are incentive contracts rigged by powerful CEO's”. The Journal of Finance, 66, pp.1779-1800

51. Muswaka, L. (2014). "The two-tier board structure and co-determination: Should South Africa follow the Germany example?". Mediterranean Journal of Social Sciences, Vol. 5, No. 9, pp.142-147

52. Naniwadekar, M. and Varottil, U. (2016). “The stakeholder approach towards directors' duties under Indian company law: A comparative analysis”, National University of Singapore, Working Paper, 2016/006

53. Nye, J.S. (1974). "Multinationals: The game and the rules: Multinational corporations in world politics". Foreign Affairs, October 1974, pp.153-175

54. Nwanji, T.I. and Howell, K.E. (2005). "The stakeholder theory in the modern global business environment". International Journal for Institutional Governance, 1(1), pp.1-12"

55. OECD (2015). G20/OECD Principles of Corporate Governance. Paris: Organisation for Economic Co-operation and Development

56. OECD (2011). OECD Guidelines for Multinational Enterprises. Paris: Organisation for Economic Co-operation and Development

57. Plumer, B. (2015). “The GM recall scandal of 2014”, Vox Media, 11 May 2015. Retrieved from Vox Media http://www.vox.com/cards/gm-car-recall/why-is-gm-recalling-so-many-cars

58. Regierungskommission Deutscher Corporate Governance Kodex. (2014). German Corporate Governance Code. Frankfurt: Regierungskommission Deutscher Corporate Governance Kodex

59. Rodriguez, M.A., Ricart, J.E. and Sanchez, P. (2002). "Sustainable development and the sustainability of competitive advantage: A dynamic and sustainable view of the firm". Creativity and Innovation Management, 11(3), pp.135-146

60. Ruggie, J. (2008). Protect, Respect and Remedy: A Framework for Business and Human Rights, Report of the Special Representative of the Secretary-General on the issue of human rights and transnational corporations and other business enterprises, John Ruggie. A/HRC/8/5, 7 April 2008, available at http://www2.ohchr.org/english/bodies/hrcouncil/8session/reports.htm

61. Russell, G.W. (2013). "Balancing the boards". A Plus, 9(3), pp.14-19

62. SAGE. (2012). SAGE Brief Guide to Corporate Social Responsibility. California: SAGE 
Publications

63. Sanchez, J.L.F., Sotorrio, L.L. and Diez, E.B. (2011). "The relationship between corporate governance and corporate social behavior: A structural equation model analysis". Corporate Social Responsibility and Environmental Management, 18(2), pp.91-101

64. Schwarcz, S.L. (2016). "Rethinking corporate governance for a bondholder financed systemically risky world". William \& Mary Law Review, Forthcoming. Available at SSRN: https://ssrn.com/abstract=2741794

65. Shahzad, A., Rutherford, M.A. and Sharfman, M.P. (2016). "Stakeholder-centric governance and corporate social performance: A cross-national study". Corporate Social Responsibility and Environmental Management, 23(2), pp.100-112

66. Simionescu, L.N. (2015). "The stakeholders ability to influence the relationship between companies financial performance and corporate social responsibility". Constantin Brancusi University of Targu Jiu, Economy Series, 2(1), pp.246-250

67. Smith, H.J. (2003). “The shareholders vs. stakeholders debate”. MIT Sloan Management Review, 44(4), pp.85-90

68. Spitzeck, H. and Hansen, E.G. (2010). "Stakeholder governance: How stakeholders influence corporate decision making". Corporate Governance International Journal of Business in Society, Vol. 10, No. 4, pp.378-391

69. Stout, L. (2012). The Shareholder Value Myth: How Putting Shareholders First Harms Investors, Corporations, and the Public. Oakland: Berrett-Koehler Publishers

70. Taneja, S., Griffin, J., Taneja, P., Sharma, R., Davidson, D and Ray, R. (2017). "Using a Stakeholder Approach to Understand Success: Empirical Tests in Indian Business”, in Aras, G. and Ingley, C. (Eds). Corporate Behavior and Sustainability. Surrey: Gower Publishing

71. Tian, J.J. and Lau, C.M. (2001). "Board composition, leadership structure and performance in Chinese shareholding companies". Asia Pacific Journal of Management, 18(2), pp.245-263

72. Tricker, B. (2009). Corporate Governance: Principles, Policies and Practices. Oxford: Oxford University Press

73. Vallejo, N. and Hauselmann, P. (2004). Governance and Multi-stakeholder Processes. New York: International Institute for Sustainable Development

74. Van der Heyden, L. (2015). "VW's board needed more outsiders". Harvard Business Review, 11 November 2015

75. Vorster, S. and Marais, C. (2014). "Corporate governance, integrated reporting, and stakeholder management: A case study of Eskom". African Journal of Business Ethics, Vol. 8, No. 2, pp.3157

76. Waddock, S.A. and Graves, S.B. (1997). "Quality of management and quality of stakeholder relations are they synonymous?". Business and Society, 36(5), pp.250-279

77. Wang, J. and Dewhirst, H.D. (1992). "Board of directors and stakeholder orientation". Journal of Business Ethics, 11, pp.115-123 
78. Webb, E. (2004). “An examination of social responsible firms' board structure”. Journal of Management and Governance, 8(3), pp.255-277

79. White, A.L. (2006). The Stakeholder Fiduciary: CSR, Governance and the Future of Boards". San Francisco: Business for Social Responsibility

80. Wood, D.J. (1991). “Corporate social performance revisited”. Academy of Management Review, 16 , pp.691-718

81. Wye College (1998). NGO Management. London: University of London

82. Zhang, H. (2003). "Foreign Direct Investment in China: 1979-2002", in Columbus, F. (Eds). Asian Economic and Political Issues - Volume 8. New York: Nova Science Publishers 